\title{
TTR
}

Traduction, terminologie, rédaction

\section{Maria Tymoczko. Enlarging Translation, Empowering Translators. St. Jerome, Manchester, 2007, 353 p.}

\section{Michael Cronin}

Volume 24, numéro 2, 2e semestre 2011

URI : https://id.erudit.org/iderudit/1013407ar

DOI : https://doi.org/10.7202/1013407ar

Aller au sommaire du numéro

\section{Éditeur(s)}

Association canadienne de traductologie

ISSN

0835-8443 (imprimé)

1708-2188 (numérique)

Découvrir la revue

Citer ce compte rendu

Cronin, M. (2011). Compte rendu de [Maria Tymoczko. Enlarging Translation, Empowering Translators. St. Jerome, Manchester, 2007, 353 p.] TTR, 24(2),

252-255. https://doi.org/10.7202/1013407ar d'utilisation que vous pouvez consulter en ligne.

https://apropos.erudit.org/fr/usagers/politique-dutilisation/ 
d'infidélité ou de faute. Et elle a raison : toute traduction et toute retraduction contribuent à l'évolution de l'œuvre.

\author{
Elisabeth Lortie \\ UNIVERSITÉ D'OTTAWA
}

\title{
Maria Tymoczko. Enlarging Translation, Empowering Translators. St. Jerome, Manchester, 2007, 353 p.
}

In the rhetoric of self-congratulation in Translation Studies, civil engineering provides a rich source of metaphor. Translators are always building bridges, opening up channels and laying foundations. And of course there are rogues on the construction site who ignore the health and safety regulations (ethics) and leave Babel with dodgy tower blocks, monumentalizing their own bad faith. Maria Tymoczko, in this important book, expresses her impatience with these complacent, irenic definitions of translation which naturalise specific Western historical experiences and universalize them as binding descriptions of what translation is and is not.

The four chapters of Part 1 consider the implications of enlarging conventional understandings of translation practice and product, while the following four chapters in Part 2 investigate the notion of the empowerment of translators. The opening chapter sketches out an alternative reading of translation in the post-war period and chapter two addresses the core issue of how translation might be defined. In chapter three, Tymoczko explores the categories of representation, transmission and transculturation and analyzes their significance for the understanding of translation, and chapter four demonstrates how a broader understanding of the nature of translation would inform different research practices. Chapter five pays particular attention to the operations of translators in post-colonial societies as a means of engaging with ideas of empowerment, and chapter six looks at how holistic approaches to translation open up new perspectives for understanding the agency of the translator. Chapter seven takes on the central importance of theories of meaning for translation, while chapter eight investigates what ethics itself might mean for newly empowered translators. 
Tymoczko posits the Second World War was a crucial point of origin for dominant theories of translation in the postwar period. If linguistic theories of translation are born out of interests in code-breaking and intelligence gathering, functionalist theories emerge from wartime concerns with effective propaganda. If the two approaches diverge, they nonetheless share a broad belief in the value of positivistic approaches to defining and understanding translation. The positivist credo will come in for much criticism from the 1970s onwards, and a hermeneutics of suspicion around language, culture and texts will bring the postpositivist paradigm into translation research. In Tymoczko's view, however, the post-positivist paradigm has not delivered on its promise and, to use the language of the revolutionary, there is much unfinished business. Part of the problem is that the implicit view of translation is one still beholden to literacy, the authority of the (written) word, power differentials, and a transfer hypothesis primarily concerned with a semantic theory of meaning. The view is largely the outcome of specifically Western engagements with canonical text formation, mainly in the area of Bible translation. So defining translation is not the idle exercise of the student debater or of the undergraduate greenhorn playing for time with extended citations from the OED, but goes to the heart of what the discipline of translations is about and where it might go.

Tymoczko's main argument is that the more we expand our definition of what translation is, the better our grasp of the many things that translation has been in different cultures in different places and at different times and, consequently, the more power and relevance we confer on translators and their agency. In the spirit of Descriptive Translation Studies, if we look at what translators actually do and how translations are in effect received, then we can begin to admit of very different forms of translation practice from those prescribed by a particular Western purview. In this context, Tymoczko draws on Wittgenstein, a philosopher who has figured in her previous writings on translation. She is particularly drawn to his discussion on the notion of game and how no one definition of game can possibly account for all the different forms of activity which are understood as games in different cultures. So, a game might be played alone (patience), with one other person (singles tennis), twenty-one other persons (soccer), or twenty-nine (rugby union). Stating that a game must 
always be played with someone else or that a game is defined by being played with twenty-one other people would exclude forms of activity that are clearly recognized as games. The notion of a cluster concept allows the theorist to accept that there are overlapping definitions of translation and that given a set of attributes, each form will demonstrate some but not all of the attributes. These attributes are immanent, however, based on what cultures and societies take to be translation, rather than transcendental or pre-defined.

The generosity of a broader, definitional impulse is generally faulted on the grounds that the map becomes as large as the territory. If anything goes in translation, is there anything that is not ultimately a translation? Tymoczko's response to this charge is to argue that the more non-Western translation practices are empirically investigated (she gives many examples) the more a broader definition of translation as a way of fitting the facts is validated. In other words, even in narrowly instrumental terms, restricted Western views of translation simply fail to do what they claim to do; account for observable evidence. For this reason, the chapter on research models is especially useful in demonstrating that post-positivist paradigms do not mean eschewing notions of rigour or validity in translation research and that such paradigms can very successfully re-interpret the range and nature of realworld data.

A signal virtue of Enlarging Translation, Empowering Translators is that Tymoczko asks fundamental questions about concepts that are far too often taken for granted in discussions in Translation Studies. Concepts like language, culture or history are relentlessly problematized and Tymoczko demonstrates the extent to which a great deal is left unquestioned in the more conventional understandings of what is intended when, for example, we talk about "text" in translation. In this respect, chapter seven is particularly valuable in its forensic exploration of what we mean when we talk about "meaning" in translation. She notes that whereas meaning is often seen as straightforward and obvious by many translation scholars and teachers, "This disposition differs sharply from the views of meaning in linguistics, philosophy and literary studies, as well as many other academic disciplines, where there is both puzzlement and contention about 
what is meant by meaning" (p. 265). She illustrates the sheer complexity of what might be said about meaning in translation by examining a short twenty-four syllable poem in medieval Irish and discussing translations of the poem produced by different students. In answer to the question, "Where does meaning reside in a text?,"Tymoczko offers a detailed table of possible responses that runs over four pages, and even this table does not do justice to the full range of possible meanings that might be said to exist. The point here is not to despair at the impossibility of the task of translation but rather to invite a healthy scepticism as to the privileging of semantic meaning as the sole arbiter of possibility and effect in translation.

Tymoczko contends that difficulties in defining translation are what constitute its strength, not its weakness. The congenital uncertainty about how to delimit the practice means that it can function in many different forms in many different cultures at many different times. The rage for order that underlies repeated attempts to define translation once and for all ignores not only the diversity of cultures and the movement of history, but fatally compromises the ability of translation to respond to crisis and change. Part of the impulse for Tymoczko's commitment to an enlarged view of translation is her wide reading in history, philosophy and cognitive science which sensitizes her to the potential of Translation Studies as a transformative discipline. As in her earlier monograph Translation in a Postcolonial Context, Tymoczko's writing is characterised by conceptual rigour, political boldness and a deep engagement with translation practices. The arguments are carefully constructed but infused throughout with a passionate concern for the importance of translation and translators to the world they help to create and shape. Enlarging Translation, Empowering Translators is a work that the engineers would ignore at their peril.

\section{Michael Cronin Dublin City University}

